\title{
Verbiage and Sensationalism in Unethical Journalism Creating Stigma and Fear during COVID-19
}

\author{
Claron Fidelis Mazarello and Tori R. Connor \\ Karl Eberhard University, Tuebingen, Germany
}

\begin{abstract}
The absence of ethics in journalism leads to chaos uncertainty and fear, during times of a crisis. We will take a close look at the unethical coverage through the verbiage and the extent of damage physically and mentally that we have been going through since the onset of the pandemic. Making it not only an infectious disease pandemic, but this has developed into a fear pandemic of its own. The study looked at the most read 200 written news reports from around the world, narrowing the search to 50 in total; 40 of the top readership and 10 to ensure the study encompassed all regions of the globe. Seeing their use of 'patient' was dehumanising resulting in stigma, 30 news sources were then scrutinized using the World Health Organisations 'Do's"' and 'Don'ts' sensitization guidelines ass per February 24, 2020,

all written reports failed in using the words known to create stigma. Coupled with these results are a plethora of research and studies compiled to bring attention to the fact stigma from infection diseases can affect the productivity of the heath care system during a pandemic, as well as result in serious lasting mental health concerns such as PTSD. As well a, charting how media is directly shown to feed the fear of crisis's by sensationalising an event and using stigmatising verbiage in reporting. This can only be described as unethical media coverage. Outlined are ways to rectify this, including the importance of a Media's apology to the world.
\end{abstract}

Keywords: Stigma, Unethical Journalism, Mental Health, Fear, Sensationalism

\section{INTRODUCTION}

$\mathrm{E}$ ffects of a pandemic are devastating, and the Coronavirus disease is no exception; with the loss of life and economic strain that already creates an environment of fear, uncertainty and unrest. All this without the added social crisis of stigmatization due to unethical media coverage through their use of verbiage that had been deemed inappropriate on February 24, 2020 by collaboration of UNISEF and the W.H.O. $\stackrel{23}{ }$ This source of guidelines followed the pre-existing globally excepted direction set buy UNAIDS ${ }^{19}$ on stigmatizing word usage and labelling, This reference was used to duplicate an appropriate set of word usage for COVID-19 outlining a total of 21 words / phases not to use FIGURE 1 including reasoning and a sensitized substitute. Social stigma, as per the perspective of those living with an infectious disease or perceived as being at risk of acquiring the disease, the stigma they experienced included shunning, marginalization, and rejection (Lee et. al., 2005*). This not only effects individuals and their mental and physical heath, but breeds a kind of fear thatmultiplies and spreads faster than the disease itself. This inevitably puts people at risk of being ostracized; and the target of violence, as reported by New York Times, April $27^{\frac{12}{2}}$, the headline read, "Nurses have been viciously attacked around Mexico at least 21 times, accusedof spreading the coronavirus." This fear that can inhibit or undermine the necessary proceedings of officials and doctors for quailing the pandemic itself. There are multiple dimensions of stigma that can negatively impact health practices and outcomes as shown by the extensive research done for HIV-related stigma (Turan B et. al., 2017*). It is not just the amount, but the type of media affected the psychological and physical response to a distressing event. It was found, that people who had exposed themselves more frequently to media about the Boston Marathon bombings demonstrated higher acute stress then ones exposed to the bombing directly (Holman, Garfin, \& Silver, 2014*). More media coverage may be sought by individuals who have a greater concern for the Coronavirus disease, only increasing their stress response, because this seems to be an accumulative event. Meaning a cycle of distress could occur, as threats continue to materialize this will automatically repeat amplified media exposure of the event (Garfin et.al.,2015*; Thompson et. al., 2019*).

The story used to introduce and to illustrate just how damaging stigmatizing verbiageby the unethical journalism in media can be, is based off an article the researcher publishing on a Goan news source, this article was written in adjacent to this study taking place, as a product of the research and was used in the research as a case study ${ }^{6}$. The case study takes place in Goa, India; depicting one 14 year old, whose death can be directly related to the effects of stigma. Their drop in oxygen levels and blood pressure came no sooner than when they heard the name of the local COVID hospital ESI; this was a reason beyond medical treatment, that got their preexisting medical condition closer to the death they inevitably succumbed to in the following morning. This was one brave child, you will see as you read their journey through treatment, considering we all will have to go to a hospital some day.

This is an example of how the atmosphere around us; during a health situation, before medical treatment, and after medical treatment, could influence our chances of surviving anyillness, this exhibits the direct impact of stigma. The World Health Organization Constitutionstates: "Health is a state of physical fitness and of mental and social well-being, not only the absence of infirmity or disease. The right to health is one of the fundamental rights to which every human being is entitled, 
without distinction of race, religion, political beliefs, socioeconomic condition. The fundamental freedoms can be obtained and maintained only when people are healthy, well nourished, and protected against disease."르 The attempt here is to define the sphere of treatment where no money or the best medical facilities will help. What helps most is a simple smile.

The more complex a problem may seem, the simpler the answer may be. We believeour findings will arrive at the conclusion that the fear psychosis among many sections of the public and the increasing stigmatization has come through the ignorance of ethics, which prohibits use of words due to the sensitivity of the situation at hand. Two antagonists have been shown to be strong, consistent predictors of stigma beliefs and stigmatization, perceptions of danger and negative affect (anger, fear, and disgust) (e.g., Smith, 2012*, 2014*). The use of these simple words can lead to widespread fear is something endorsed heavily by the human rights organizations around the world including; UNAIDS, World Health Organization, UNICEF and all other medical organisations, including the $\mathrm{CDC}^{5}$ in the USA and $\mathrm{ICMR}^{9}$ in India. The issue of vaccines was also to be sensitively published. In no way, were the media supposed to make the public feel that a vaccine was the only way to be saved from this virus. The fact that_this was not to be reported with emphasis was declared along with; masks, social distancing, quarantines and lock downs. This provided a false sense of security, this 'security' was fed to the public uncensored by the media. All the while, the mental health effects of lock downs, social distancing, isolation and quarantine that have been well documented. As seen in a rapid review done on the psychological impact of quarantine in the UK, a quote by a male participant in his 20 's stated, “...some participants found that being locked at home coupled with constant media and social media attention on COVID-19 made them feel "claustrophobic in both a physical and an emotional sense"" (Williams et. al.,2020*). These examinations must be taken into the media's consideration when reporting ethically, sensationalizing these issues feeds the fear.

The implementation of this ethic and passing this on, comes from what everyone reads, from a source that has a license to publish for the masses. Here lies the whole issue of non compliance of ethics, when publishing material for the public sends out the wrong signals to the mind about things that have been agreed upon by humanitarian standards like; rape, violence, drugs, diseases and matters alike that demand sensitivity and are affected by sensationalism in the Media. Information should also be provided by the media without sensationalism or disturbing images (Garfin et. al., 2020*). While keeping in mind that witnessing the traumatic, and difficult course of the infection in others can result in fear and anxiety about becoming ill or dying themselves (Van Bortel et. al., 2016*). While guidelines for the above spoken agreeable terms have been specifically acknowledged around the world, the current issue of the COVID-19 pandemic that also vindicates this stance of sensitivity is what is being explained here. To further emphasise the URGENT NEED FOR IMPLEMENTATION OF ETHICAL STANDARDS WITH ALL PUBLIC PUBLICATIONS.

Every death matters; revealing names, allowing misinterpretation of the words, 'DEATH TOLL' in upper case, and region labelling are all found to generate fear and stigmatization. The model of stigma communication details how; messages with certain typesof content bring to mind preexisting perceptions, and the affects of these cognitions in the development of stigma beliefs and stigmatization, including support for public policies regulating stigmatized people, interpersonal dissociation from stigmatized people, and the social transmission of the stigma messages (Smith, 2007*, 2011*). Relatively, studies on disaster media coverage have examined long-term psychological outcomes, including; PTSD, depression, anxiety, stress reactions, and substance use (Pfefferbaum et al., 2014*) In fact we are able to use the judgement of the High Courts of three separate states in India who already ruled against 2 PILs asking for the release of names for positive acquisitions, ${ }^{2,} \underline{16}$ In favour of a PIL for a complaint made against officials, when names of people living with COVID-19 were revealed, the High Court asked the state, to 'ensure Covid-19 patients' identities are protected. ${ }^{7}$ This put into question the motive and necessity of revealing names of people contracting COVID-19 to the public, "There is always a risk of ostracization," were the words of Chief Justice Datta, on the Bombay bench, ruling this PIL ${ }^{15}$. Here are the bare issues of sensitivity; which if not upheld by ethics, leads to stigmatisation and persons beingostracized, as the learned judge also felt.

While the name and gender of this 14 yr old was not revealed by the media reporting, due to reasons of sensitivity, there death was classified by all news media as part of the 'deathtoll' for COVID-19. The death was not a direct COVID death but was largely due to previousailments of the lungs and kidney. The most important element here, which is the main reason for this research, is to expose the aspect of mental health and how it is directly affected by stigma, which is increased by insensitive verbiage and sensationalizing the infections disease; with cases and death tolls. Also, by vaccines, lock downs, social distancing and masks being shown as the only hope in a pandemic by the media. The research into the death of this 14 year old highlights these aspects as this was very close to a 'fear death' - or broken heart syndrome, which is death due to anxiety that cannot be handled physically after break down of mental health. 11 The part that makes this clear is the element that made this child break down. Unable to be taken to a designated hospital for COVID treatment, even while an ambulance waited this transfer from the hospital they were at, instead had to be put on ventilators due to a drop in their oxygen levels. The drop in oxygen levels happened at a particular point, when the parents were told, in front of them, that they needed to go to 'ESI Hospital'. Hearing this information apparently triggered this person's oxygen levels to drop. 
The story ends soon after the ventilator. The very next morning, the child succumbed.

The young child's strong reaction to the words ESI Hospital was clearly due to the atmosphere created by their environment; the stigmatization of the hospital itself which hasdeveloped a reputation of being called a 'shamshan ghat' meaning a crematorium in the Hindi language. This hospital once a place for healing has now been branded as a crematorium. This was not only acknowledged by those from where this child lived, which had itself been targeted by the media's stigmatizing sensationalism of COVID-19, but by every Goan. This brought them to feel or react in a particular way upon hearing the very name of this hospital. This had nothing to do with any medical treatment, or any drug a pharmaceutical company could provide. But this greatly affected their treatment. In this case, this became the reason for a death, as per the sequence of events as told to us by the person aiding this child, and supported again by people who knew them and their family well enough. This child's story is supported by recorded quotes from the ward councillor where they resided, as well as quotes from more residents of the locality about the fear factor everyone had developed with regard to a COVID hospital.

The reason for the widespread role reversal of a hospital cannot be limited only to rumours coming from one particular location. Here is where the regional labelling prescribed as a 'don't' in relation to stigmatisation* becomes an important topic. This happened simply by the lack of sensitivity from mass media covering this virus all over the state of Goa. Goingback to February the state of Goa has been sensationalizing the COVID-19 pandemic, using their 4 most read newspapers to highlight and headline places in Goa being affected by this disease. They have accomplished this by their daily use of regional labelling, disclosure of names and places of those persons' who have acquired COVID-19, sensationalizing deaths and case increases, and blindly using labels to trigger fear and anxiety such as; victim, suspect, patient, and infected. Bulks of information may dangerously increase the perception of risk and these fear-based messages by the media are shown to have negative effects on the general population who cannot discern real from fake news. (Kasperson et al., 1988*). Also messages with 'high' stigma vs 'low' stigma were shown to be shared more often and accompanied with a request or demand to pass it on, such as "share this with everyone you know," (Rachel A. Smith et. al., 2019*). We must realize the importance of this; the world has been exposed to mass amounts of information on the coronavirus disease, full of mixed messages, unclear information and most importantly to note; stigmatizing words. With this study we will bring into the light that this has not been an isolated case of stigmatization byunethical journalism but that this has been happening constantly in every region around theworld.

This brings us to the macro picture, from this micro viewing of a case study of a particular place, for the purpose of research. The macro picture is where more than 50 out of 200 top media houses, were scrutinised, and then 30 were individually examined and photographic evidence collected as screenshots, to prove that this error of ignoring ethical standards has been ignored all over the world. A review of the final thirty that have been spread over the entire globe area, both with respect to clustered areas of media houses as wellas isolated media houses covering distant regions, all in a bid to cover the globe's area as uniformly as possible. This also included information of approximate readership, this information was gathered by doing a Google search if it could not be found on new sources webpage, these searches resulted in monthly readership figures. This large readership has also been taken into consideration when choosing the final thirty. These should provide enough and sufficient reason to have ethics restored in journalism, because with the absence of ethics; chaos, uncertainty and fear ensues and with this stigmatization is born and multiplied. As for documentation of the individual fear, we will have to rely on videos. This case study had to be brought down to micro level again taking us back to the story of the 14 year old who died, where there are videos made by individuals from this place as well as other places in Goa asking people to stay away from and stigmatising people who have contracted this virus. One such video was made by, Goan Reporter News, where a priest from this labelled region in Goa, gives out details of how he was ostracised ${ }^{10}$. His testimony, and that of the ward counsellor from where this child died, also documenting the responses of the people that they were not willing to come out for testing given that they would be stigmatised, and multiple articles ${ }^{8}$ reviewed of health facilities refusing treatment or demanding a negative test results before performing treatment for serious ailments unrelated to COVID-19, solely because the place they come from carries so much stigma. Ethical journalism is where the motivation to this research began, with a vision to use this to promote ethic in society through sensitisation, starting with COVID times, so that the entire concept of sensitisation and ethic itself get its required place in society. The chaos without this was the concern; especially as this was happening, not in full consciousness.

\section{METHOD}

Mixes of qualitative and quantitative research methods were used. Basing the main design on phenomenology; it was believed that unethical journalism across the world was a cause of stigma in reference to COVID-19. Stigma is a phenomenon that has been going on for decades with other infectious diseases such as SARS, HIV, H1N1, and TB. The research is structured to help determine if as a general population we are unaware of the effects of unethical journalism and how it directly affects the stigma of infectious diseases and what impacts this has on those suffering from stigma as well as those stigmatizing. To show this we used a quantitative approach by accumulated previous studies supporting the affects of stigmatization as well as how media coverage can increase such sigma. We also used a qualitative case study approach by doing a micro study; 
looking into the death of the 14 year old and the affects stigma can have on an individual, performing verbal interviews, and getting recorded testimonies from their ward counsellor and people with them during these events as well as doing a compilation of videos from people in this community who have been ostrasized and alienated. We also used the case study design in a quantitative sense to look at 200 news sources, narrowing it down in 3 phases to an in-depth look at 30 news papers for the stigmatizing verbiage. Using the 200 news papers and keeping a world view inmind was our way of ruling out possible conspiracy theories that had been rumoured on social media platforms.

The researcher has the professional background of a free lance journalist since 1999, sub editor at Goa's first political audio visual channel, and the project manager of an NGO working with elements of theatre to help spread important social messages. Which led to conducting a sensitisation workshop with the police force and the way they fight their 'war on drugs' was hurting the work of the NGOs. During this time period, while working with a newspaper, the researcher was given a sensitisation workshop on HIV virus, thus giving all insight required for the concept of stigma and sensitivity. More currently working with, TueNews; a refugee project in Germany, as a journalist and event manager for purpose of integration. Also with specially-abled people; organising music and dance healing workshops, taking into consideration their type of special ability, as well as being a personal helper and assisting life services of these individuals. This experience helped with the further understanding of the sensitivity that needs to be considered and the stigma that needs to be reversed.

The demography and environment from the above work areas, has led to experiences of how many things are omitted with mainstream structures. For instance, treatment of drug abuse persons, how the law handles these people, also with regards to crimes involving rape and violence. Being a journalist exposed insight to many short coming that can also be seen as injustices. Given this background, coupled with a degree in Sociology and Economics, when the W.H.O. document suggesting sensitivity was found sometime in April, the question of sensitivity was here connected directly to ETHICAL journalism.

This is being studied with the background of the; influence of the media making or breaking an individual where word of mouth is the most reliable way of spreading some news. This word of mouth, like learnt and copied behaviour, relies on phrases read. These are then repeated and the conversation links stereotype over stereotype, thus making assumptions on one's own. The root however of information seems to be none other than media. The science of word stimuli as confirmed in the studies referenced, applies irrespective of particular spaces, along with this philosophy of sensitivity, is enough reason to claim the general insensitivity from the media. Just as the evidence will clarify.

AIM - HOW ALL MAJOR MEDIA HOUSES
CREATED STIGMATISATION, BY IGNORING ETHICAL JOURNALISM AND SENSITISATION GUIDELINES PRESCRIBED BY W.H.O. BEFORE THE COVID PANDEMIC IN FEBRUARY*; THIS BEHAVIOUR HAS CONTINUED AS DOCUMENTED TO THE END JULY! By the end of

this report we all will be asking for an apology.

\section{PHASE I}

Starting this study with a simple, random Google search 'top newspapers in world' as the algorithm already suggests. The second search option, after Wikipedia, read Top 200 Newspapers in the World by Web Ranking ${ }^{1}$. This gave a list, from where the first forty were copy pasted in an individual search. Then Google was used to search for the words 'Coronavirus patient news on ...' then adding names of each of the newspapers one by one. Onevery search, either the newspaper in concern was directly checked, as soon as the words Coronavirus patient appeared in the highlighted words in each instance of the Google searches. Or, a choice was made within the first five searches listed, that inevitably had the words we were looking for. We first tried to pick a source from the original newspaper, unless there was no English edition available we would then search for another written news source from the same country, Instances when the choice had to be made from more than five of the top searches featured were duly noted. After reaching 40, a list of 10 newspapers were collected to spread the experiment to regions across the world not previously covered in the original forty. This was especially done to confirm these incidences as being pure coincidence; and that this verbiage leading to stigmatisation was not implemented by a

1 4International Media \& Newspapers, 2019 Newspaper Web Rankings. https://www.4imn.com/top200/ particular country or even continent but collectively. Note - Greenland was the only region we could not duly cover because neither of their national newspapers had an English edition and Google translate was thought to cause potential bias in verbiage making the results non-conclusive. TABLE 1 at end of the document shows all 50 News Sources used, with links to the article used with Key-Word 'Patient'.

\section{PHASE II}

All 50 were checked again for compliance with only W.H.O. guidelines; verbiage such as; COVID-19 / Coronavirus cases, infected, and transmitted, as this was internationally ethically supposed to be implemented. In the recheck, readership claimed by each of these news publication houses that was available, was found, this showed the extent of DAMAGE from end of February onwards based on the amount on people who on average who are taking in these stigmatized messages constantly. A study done in 2009 concluded each additional hour of average TV viewing was associated with a $15.6 \%$ increase in the proportion of people worrying about infectious diseases like H1N1 (Jan Van den Bulck \& Kathleen Custers., 2009*). We must also note, from 
the analysis by (Frye, William B. In 2005*), that sensationalism is a type of framing, used by journalists; this is when a story is exaggerated or given a certain tone by the writer, media has rationalized this type of framing because it 'brings an audience'. Because fear is a human emotion that can accumulate over time, continuous barrage of stories that denote fear in the news, results in people beginning to associate the subject matter with fear. The facts that sensationalizing is a type of media framework that has been used for decades, we can conclude that the general population are unaware about the majority of unethical journalism taking place, and although felt, the publicmight not recognise what is causing the fear and stigma about crisis topics.

More than 50 unrecorded verbal opinions by journalists, NGO workers, and known acquaintances, were taken from individuals who were asked to review articles in an attempt to keep personal bias away. All 50 came to conclude that the fear unknowingly propagated knee jerk reaction leading to authoritarian leadership taking shape, leading to violation of human rights by institutions like police force and doctors and of course media with this ignoring of W.H.O. and human rights endorsed sensitive verbiage that no one was conscious of. Other observations made were, rash handling of statistical figures with no disclaimers or direction for the readers to take. Examples of this would include the daily tally of Coronavirus cases, and Death Tolls usually depicted in bold and coloured headlines that leads to uncertainty, fear, high insecurity and health risking anxiety.

\section{ANALYSIS}

All 50 were guilty of violating W.H.O. verbiage guidelines. The evidence is gathered with respect to links as on July 20. These may be changed no sooner than this report is out. However, this has been witnessed by the world, and with this we believed every news source needs to recognise and be held accountable for stigmatizing the COVID-19 pandemic with misuse of already outlined words. After this review we decided that additional examination was needed to be sure we kept our methodology integrity, by further probing 30 of the 50 newspapers. Wanting to be sure that a 'copy paste' mentality was not being used; the 30 articles we were analysing would be no earlier than July 1, 2020, also the 'Don't' verbiage as specified by the W.H.O.* would be considered in context to make sure it was not a 'copy - paste' scenario, for example 'Coronavirus cases' being highlighted when the article was stating the amount of Coronavirus acquisitions in an area or country, was not to be excepted, we wanted to make sure the words in question were written in such a context that it triggered a feeling of fear, anxiety or direct stigma and discrimination. 5 more lay people also reviewedthese findings, but they realized they were not aware of the entire sensitivity guideline necessity in the media they could only judged once they were explained about the lake of ethics, this however only led to a bias judgement. In order to compensate for this it was canvassed by 3 more individuals who were already aware the sensitization context from their own sources, for instance NGO workers who are aware of sensitization. They considering this was over site by media itself, the very representation of these documents were a novelty to every other person not in the media. 5 media personal also agreed and admitted to the violation of these guidelines

\section{The Additional Phase Iii Of This Experiment}

Of the 50, 30 were chosen based off highest readership while keeping out regional spread, they then were closely scrutinised for the W.H.O. guideline verbiage specifically. Forthis procedure, we went to the media source page and searched the article for key words, 'COVID-19 cases, coronavirus cases, victims, infection, transmission and region labelling.

While more instances revealed blatant ignorance of the very philosophy of sensitivity in such situations, this was specially reviewed by two different people; one male and one female.

When the words were found, these were highlighted and screen shots were taken to have this as evidence for each of these 30 from different parts of the world. All screen shots and evidence gathered is from the month of July, thus leaving no room for saying that this was anoversight but that this was long overdue, and continues to be of utmost importance.

\section{The Findings Say One Thing - This Is Clearly Unethical Journalism!}

Forming or breaking stigma is a media construct; in this sense not considering the

W.H.O. guidelines with an excuse of credibility of information does not exist. Simply, because the element of sensitisation is what every journalist goes through depending on how serious the state administration is about such sensitisation programs and has nothing to do with scientific facts except for clarification in using the right language to address these very scientific facts, all ambiguities and all concerns especially when insecurities are high. Even terms such as "patient" should be morally questioned and avoided when not using in a clinical setting, the word patient runs the risk of dehumanizing the individual because the words we use can disillusion us from the fact that a label or diagnosis does not define a person ${ }^{17}$. This being a human responsibility, the error is understandable, nonetheless an apology is a must in this case, to start setting things in the right direction.

TABLE 2, outlines what we discovered in PHASE 3, includes 30 newspapers and their country of origin, whether they 'passed' or 'failed' according to the WHO verbiage guideline*, their approximate reader-ship as stated before 2020, to account for the possible increase due to COVID-19 after 2020. Finally we have a link, through the publishing date, to the website article page with the Key-phrase (as per W.H.O. guideline) that was found to enforce stigma and sensationalism. 
TABLE 2

\begin{tabular}{|c|c|c|c|c|}
\hline $\begin{array}{l}\mathrm{Sr} \\
\mathrm{Nr}\end{array}$ & $\begin{array}{l}\text { PUBLICATION\& } \\
\text { COUNTRY }\end{array}$ & $\begin{array}{l}\text { PASS or } \\
\text { FAIL } \\
\text { W.H.O. } \\
\text { word } \\
\text { guidelines }\end{array}$ & $\begin{array}{l}\text { READER- } \\
\text { SHIP } \\
\text { CLAIMED } \\
\text { (Apprx.) }\end{array}$ & $\begin{array}{c}\text { ARTICLE ATTACHED TO PUB. DATE VERBIAGE } \\
\text { AGAINST W.H.O GUIDELINES } \\
\text { Date \& Time discovered for research }\end{array}$ \\
\hline 1 & INDEPENDENT,UK & FAIL & $\begin{array}{c}24.5 \\
\text { million }\end{array}$ & $\begin{array}{l}\frac{01 / 07 / 2020}{11: 51 \mathrm{pm}}-\text { Key-phrase: } \begin{array}{c}\text { COVID-19 victims - found, } 21 \text { July } \\
\text { Additional note }\end{array}\end{array}$ \\
\hline 2 & $\begin{array}{l}\text { DAILY MAIL } \\
\text { ONLINE, UK }\end{array}$ & FAIL & 2.3 million & $\underline{26 / 07 / 2020}$ - Key-phrase: Transmission - found, 22 July1:05am \\
\hline 3 & $\begin{array}{l}\text { THE WALL } \\
\text { STREET JOURNAL, } \\
\text { U.S.A. }\end{array}$ & FAIL & 2.8 million & $\begin{array}{l}\text { 21/07/2020 - Key-phrase: COVID-19 cases - found, 22July 1:38am } \\
\text { **Limited access without subscription }\end{array}$ \\
\hline 4 & $\begin{array}{c}\text { CHINA DAILY, } \\
\text { China } \\
\end{array}$ & FAIL & 900,000 & 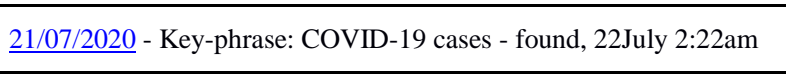 \\
\hline 5 & $\begin{array}{l}\text { WASHINGTON } \\
\text { POST, U.S.A. }\end{array}$ & FAIL & 86.6 million & $\begin{array}{l}\text { 18/07/2020 - Key-phrase: persons infected - found, } 22 \\
\text { July 1:49am }\end{array}$ \\
\hline 6 & $\begin{array}{l}\text { SYDNEY } \\
\text { MORNING } \\
\text { HERALD, Australia }\end{array}$ & FAIL & 7.9 million & $\frac{20 / 072020}{03: 00 \mathrm{pm}}$ - Key-phrase: COVID-19 victims - found, 11 Sept. \\
\hline 7 & $\begin{array}{c}\text { THE ASAHI } \\
\text { SHIMBUN, Japan }\end{array}$ & FAIL & 6.41 million & $\underline{\text { 26/07/2020 }}$ - Key-phrase: COVID-19 cases - found, 22July 02:31am \\
\hline 8 & $\begin{array}{l}\text { NEW YORK } \\
\text { TIMES, U.S.A }\end{array}$ & FAIL & 3 million & $\begin{array}{l}\text { 17/07/2020 -21/07/2020 - Key-phrase: COVID-19 } \\
\text { cases - found on, } 22 \text { July, 02:38 }\end{array}$ \\
\hline
\end{tabular}

*While doing our first search of the INDEPENDENT, using the key-phrase COVID-19 cases, there was a link to an article headlined 'Florida governor heckled after COVID-19 cases continue to spike' but when this was clicked to open the report, the headline changed to Coronavirus cases, which was not specified under the guidelines. This was seen as a space saver move while alternating between two terms of COVID 19 cases and Coronavirus cases - where both meant the same. Let's not ignore the word 'cases', prescribed by W.H.O. to be discontinued was ultimately used in both cases. This does imply logistical word arrangements, while missing the point and fuelling stigma instead.

\begin{tabular}{|c|c|c|c|c|}
\hline $\begin{array}{l}\mathrm{Sr} \\
\mathrm{Nr}\end{array}$ & $\begin{array}{l}\text { PUBLICATION\& } \\
\text { COUNTRY }\end{array}$ & $\begin{array}{l}\text { PASS or } \\
\text { FAIL } \\
\text { W.H.O. } \\
\text { word } \\
\text { guidelines }\end{array}$ & $\begin{array}{l}\text { READER- } \\
\text { SHIP } \\
\text { CLAIMED } \\
\text { (Apprx.) }\end{array}$ & $\begin{array}{c}\text { ARTICLE ATTACHED TO PUB. DATE VERBIAGE } \\
\text { AGAINST W.H.O GUIDELINES } \\
\text { Date \& Time discovered for research }\end{array}$ \\
\hline 9 & $\begin{array}{l}\text { THE GUARDIAN, } \\
\text { U.S.A. }\end{array}$ & FAIL & 2.8 million & $\underline{26 / 07 / 2020}$ - Key-phrase: COVID-19 cases - found, 22July 03:06am \\
\hline 10 & $\begin{array}{l}\text { USA TODAY, } \\
\text { U.S.A. }\end{array}$ & FAIL & 2.6 million & $\begin{array}{l}\text { 08/07/2020 - Key-phrase: COVID-19 cases, Labelling } \\
\text { - found, } 22 \text { July 03:23am }\end{array}$ \\
\hline 11 & $\begin{array}{l}\text { EL PAIS, } \\
\text { Spain }\end{array}$ & FAIL & 65 million & $\underline{23 / 07 / 2020}$ - Key-phrase: Victims - found, July 2204:15am \\
\hline 12 & $\begin{array}{r}\text { HOUSTON } \\
\text { CHRONICLE, } \\
\text { U.S.A. }\end{array}$ & FAIL & 825,000 & $\underline{17 / 07 / 2020}$ - Key-phrase: Infected patients - found, 22July 04:39am \\
\hline 13 & $\begin{array}{c}\text { BBC, } \\
\text { News Media House }\end{array}$ & FAIL & 18 million & $\begin{array}{l}\text { 18/06/2020 - Key-phrase: COVID-19 deaths, infected } \\
\text { - found, } 22 \text { July 04:56am. 17/07/2020 - Key-phrase: } \\
\text { COVID-19 cases - found, 22 July 04:59am }\end{array}$ \\
\hline 14 & $\begin{array}{l}\text { INQUIRER, } \\
\text { Philippines }\end{array}$ & FAIL & 50,000 & $\begin{array}{l}\text { 27/07/2020 - Key-phrase: Labelling, Infected withCOVID-19 - } \\
\text { found, 22 July 05:06am }\end{array}$ \\
\hline 15 & $\begin{array}{l}\text { REUTERS, } \\
\text { News Media House }\end{array}$ & FAIL & 33 million & $\begin{array}{l}\text { 27/07/2020 - Key-phrase: COVID-19 cases - found, 22July 05:33am. } \\
\text { 27/07/2020 - Key-phrase: COVID-19 } \\
\text { infection - found, 22 July 05:38am }\end{array}$ \\
\hline 16 & $\begin{array}{l}\text { MEDUZA, } \\
\text { Russia }\end{array}$ & FAIL & 7 million & $\begin{array}{l}\text { 23/04/2020 - Key-phrase: Coronavirus infections - } \\
\text { found, } 22 \text { July 06:00am }\end{array}$ \\
\hline 17 & $\begin{array}{l}\text { THE GLOBE AND } \\
\text { MAIL, } \\
\text { Canada } \\
\end{array}$ & FAIL & 7.4 million & $\begin{array}{l}\text { 26/07/2020 - Key-phrase: Infections - found, } 23 \text { July12:30am. } \\
* * \text { Limited access without subscription }\end{array}$ \\
\hline 18 & FOLHA, Brazil & FAIL & 30 million & $\underline{27 / 07 / 2020}$ - Key-phrase: Infection - found on, 23 July23:03pm \\
\hline 19 & $\begin{array}{l}\text { HURRIYET DAILY } \\
\text { NEWS, } \\
\text { Turkey }\end{array}$ & FAIL & 6,000 & $\underline{23 / 07 / 2020}$ - Key-phrase: Infections - 23 July 23:14 pm \\
\hline 20 & $\begin{array}{c}\text { DEUTSCHE } \\
\text { WELLE, Germany }\end{array}$ & FAIL & 29 million & $\begin{array}{l}\text { 09/05/2020 - Key-phrase: Infected person - found on, } \\
\text { 23 July 23:19pm }\end{array}$ \\
\hline
\end{tabular}




\begin{tabular}{|c|c|c|c|c|}
\hline 21 & $\begin{array}{l}\text { DIARIO AS, } \\
\text { Spain }\end{array}$ & FAIL & 200,000 & $\frac{22 / 07 / 2020}{23: 07 \mathrm{pm}}-$ Key-phrase: Infections - found on, 23 July \\
\hline 22 & $\begin{array}{l}\text { TIMES LIVE, } \\
\text { South Africa }\end{array}$ & FAIL & 137,000 & $\frac{27 / 07 / 2020}{12: 23 \mathrm{am}}$ - Key-phrase: Infections - found on, 23 July \\
\hline 23 & $\begin{array}{l}\text { MEED.COM, Saudi } \\
\text { Arabia }\end{array}$ & FAIL & & $\frac{22 / 07 / 2020}{22: 52 \mathrm{pm}}$ - Key-phrase: Infection - found on, 23 July \\
\hline 24 & $\begin{array}{l}\text { NORDSTJERNAN, } \\
\text { Sweden }\end{array}$ & FAIL & & $\begin{array}{l}\text { 22/07/2020 - Key-phrase: Infected person - found, } 23 \\
\text { July 01:08am }\end{array}$ \\
\hline 25 & $\begin{array}{l}\text { SORTIR A PARIS, } \\
\text { France }\end{array}$ & FAIL & & $\begin{array}{l}\text { 29/07/2020 - Key-phrase: Infected by COVID-19 - } \\
\text { found, } 22 \text { July 05:12am }\end{array}$ \\
\hline 26 & $\begin{array}{c}\text { EYE ON THE } \\
\text { ARCTIC, Canada }\end{array}$ & FAIL & & $\begin{array}{l}\frac{22 / 07 / 2020}{\text { found, } 23 \text { July }} \frac{29 / 07 / 2020}{12: 14 \mathrm{am}} \text { - Key-phrase: Infected - } \\
\text { - }\end{array}$ \\
\hline 27 & $\begin{array}{l}\text { AL JAZEERA, } \\
\text { Qatari }\end{array}$ & FAIL & & $\begin{array}{l}\text { 26/07/2020 - Key-phrase: COVID-19 cases - found } \\
\text { July 22 01:41pm }\end{array}$ \\
\hline 28 & $\begin{array}{l}\text { THE SUN, } \\
\text { UK }\end{array}$ & FAIL & 29 million & $\frac{17 / 07 / 2020}{222: 02 \mathrm{pm}}$ - Key-phrase: Infected person - found, July \\
\hline 29 & $\begin{array}{l}\text { NEW DELHI TV, } \\
\text { India }\end{array}$ & FAIL & 13 million & $\begin{array}{l}\text { 29/07/2020 - Key-phrase: COVID-19 cases - found, } \\
\text { July 22 01:41pm }\end{array}$ \\
\hline 30 & $\begin{array}{l}\text { YAHOO NEWS, } \\
\text { USA }\end{array}$ & FAIL & 8 million & $\begin{array}{l}\text { 30/07/2020- Key-phrase: Infected person, 'Patient } \\
\text { Zero' labelling - found, July } 22 \text { 02:02pm }\end{array}$ \\
\hline
\end{tabular}

\section{Limitations}

Limitations include; video, recorded, written and verbal proof of stigmatization were sourced from Goa, India only, while many more videos of stigmatisation have come up on social media and a record of these from different parts of the world exists it was decided the case study closest to understand the situation in a known local context was the best way of recording this fear pandemic. This study was also limited to written news sources and did notevaluate the effects of television coverage of COVID-19. Also the only stigmatizing word guideline used to evaluate the news sources was from the W.H.O. and they were not further reviewed with the more thorough guidelines that created for COVID-19 during this study

While completing this research it became clear that other studies would greatly increase the understanding of these stigmatic and sensationalistic habits the media had developed. One such study could be measuring the effects of media sensationalizing the use of masks, lock downs, and social distancing around the world and to what degree of harm is done when the government decisions to enforce such mandates without due risk assessment. Another beneficial study would be the stigma and fear associated with sensationalizing statistical figures, what type of affect does seeing a non-universal depiction of; coronavirus cases, death tolls and arguable recovery rates, on a daily basis.

\section{RESULTS}

During any crisis, media delivering accurate and upto-date information is expected and relied on by the public to adopt the appropriate health precautions and behaviours. It is essential that a reliable source detailing risk assessments and recommendations are presented (Lachlan et. al., 2016), because an increase of the public's reliance on the media may happenduring times of uncertainty (Ball-Rokeach \& DeFleur, $1976 *)$.

With evidence of not following ethical guidelines of covering the pandemic collectedin this study beginning in the month of July, and the words found in the evidence were from the notification of the W.H.O. last updated on February 24, $2020^{*}$ it is seen beyond a doubt, this ignorance of sensitivity and catering to the fear was done unintentionally. The impact of this as seen from the tally of the approximate readership of each of these 30 final newspapersshows the extent of damage to billions of minds. It was also found that the damaging effects of sensationalizing lock downs, social distancing, masks and vaccines, as being our only means of returning to normal, was not recognized or considered by the media. This over-site fuelled the `fear-pandemic` instances of lock downs, social distancing and masks were than used as measures to overcome this fear, without doing any risk assessment. This resulted in people developing the idea that these prevention measures were the only option, in multiple instances selfimposed lock downs became a common call of action by people in the villagesin Goa, India, this was clearly a product fear, as reported by the HERALD, July 5, $2020^{13}$.

These community orchestrated lock downs, in spite of economic hardships, were done in order to save themselves from what the newspapers called 'deadly virus' while giving figures of case increase and death toll, in upper case, this exposes the depth of the fear caused.

A common excuse for not using sensitive language for COVID-19 coverage was, 'Noone is following this...' This also spelt out the limitation of this study to implementation off this Ethic, even though this has nothing to do with curbing freedom of speech as well. This does mean that although this research will be useful to get this done worldwide (make mandatory

ALL licensed mainstream media comply with a People First language for sensitisation standards not only for COVID, but also rape, violence, drug crimes, and the like which the media can actually help discover, all eventually) the practical implementation is seen as a limitation, logistical as it may seem in this process of world betterment, where the 
media responsibly passes on sensitivity to the public.

We also found that the fear induced by the media's stigmatizing propaganda lead to violence against many different groups of people, most notably were people who looked to be of Chinese descent, as was reported by NDTV, March 17, 2020,, 'An Indian-origin Jew was badly beaten by two people who called him a "Chinese" and yelled "Corona! Corona" in Israel's Tiberias city.' Foreigners, homeless, migrant labours, and people who "violated" authoritarian rules also fell victim to fear based violence. In an analysis made by (Link et al., 2001*) stigma coincides with the over reach of power, concluding, "Stigma exists when elements of labelling, stereotyping, separation, status loss, and discrimination occur together in a power situation that allows them" (p.377). Authoritarianism and fear lead to cases of police brutality for things such as, not wearing a mask ${ }^{18}$. Apart from this, there was a case of police brutality which ended up in a gruesome death of a father and son duo, when they were merely trying to survive the economic crisis by keeping their shop open during lock down ${ }^{3}$.

Fines, arrests and instances of violence for not adhering to rules, however misguided, encouraged authoritarianism - which not only led to mass violation of human rights, but also personal freedom, and the loss of not being able to take one's own course of medication for healing from any ailment. In India, neither the state government of Goa, that opted for a mandatory mask policy, nor the newspaper Times of India's, with their media mask campaign had made any risk based assessment on wet masks and feasibility during monsoon rains, "All masks should be changed if wet or visibly soiled, a wet mask should not be worn for an extended period of time." Advised the W.H.O..$^{21}$ Neither did they consider India has no proper medical waste disposal systems, the counter productivity during rains as well as the exposure to these masks predominantly among the underprivileged population ${ }^{1}$, could lead to lives being lost as well. However this too was ignored.

The media's insensitivity has been passed on to the general public and has further poured out into social media forums. Social media is where the ethical guidelines cease to exist. Here, the mainstream and licensed, hence, responsible media were supposed to hold the ethical fort to bring out the clear difference. However, this ceased to happen. Even as this is written, journalists are aware of this, and are not able to individually do anything, unless the editors are sensitive enough. However, these people are also human and an ironic part is that they themselves have been affected by the fear after not adhering to ethical use of words. This circle of fear needs to be considered consciously so as to not get into a blame game. Blame games will only be counterproductive, where apologies will help us move on.

The instances of fear deaths may not be able to be sufficiently supported as long as these ethics are not acknowledged. But fear is a real and dangerous result of stigma, as the UNESCO Chair on housing at the University
Rovira i Virgili of Tarragona in Spain quoted, "another type of stigmatization arose out of the fear of being infected. ${ }^{20}$, The UNESCO site included the report from the University of Córdoba of healthcare professionals who were asked, with the intention of them not 'contaminating their neighbours, ' to not to return to their homes, this article pointing out homeless were also targeted with aggressive stigma due to their inability to comply with the established preventive measures. This fear caused by stigma; from both the person potentially living with COVID-19 as well as the health professionals themselves, as per the case study in the introduction, goes beyond all treatment that can be seen, yet greatly affects the treatment. We, the people who are in need of health services, are dependent on the very attitude of the caregivers and greatly susceptible to the stigmas created around such aid. Recording this abstractness has been an issue. However, assuring ethical journalism will help cross this boundary, as suggests. Mental health has to be acknowledged for this, and according to all doctors who have reviewed the case study in the introduction, about the 14 year old, has agreed upon the simple fact that a positive mind is imperative for everyone during a pandemic. Hence the apology can help everyone, which if mirrored by the masses, will bring about a better level of acceptance that consciousness is not constant. Acceptance of this on a mass level will automatically bring about individualaccountability; the press will be setting a precedent!

\section{DISCUSSION}

The study based evidence of media messages resulting in fear and stigmatization of infection diseases, labelling causing stigmatization and the affects of stigmatization on mental health and how it can negatively impact how health organizations and governments are able to deal with the pandemic is insurmountable. With this knowledge readily available and organizations like, the Press Council of India, and Forth Estate COOP in the United States, put in place all over the word to ensure and promote ethical journalism. We must now implore the courts to step in, making rulings to help media recover and restore ethics in journalism, because, even after the media in India; including BBC India, was made aware of the ignorance of ethical guidelines and sensitivity it was ignored, which exposes the stage of denial of fear. There is no excuse, any journalist or editor after hearing these ignored important ethical guidelines, should not do his or her best to set things right from now onwards at least. The fact that this did not happen leads us to an analyses of how fear works. This may bring us to this point out in the CERD report on, the Psychology of a crisis, a CDC document stating the importance of considering the psychological fear in the response to a perceived threat, "Fear of the unknown or fear of uncertainty may be the most debilitating of the psychological responses to disasters and prevent people from taking action. ${ }^{4,}$

While it was a task to help everyone to understand the importance of mental health in these times of crisis, and how media play a vial role in the stigmatization of an event. 
This research has uncovered that the media is accountable for reporting without ethics and sensitivity for over six consecutive months, to help everyone unlearn the stereotypes now learned we must seek to stop the trickle down of these words triggering fear, into public conversations from reproducing what they read and heard in the media, and into social media also needs to be addressed. Hence, ideally the mainstream media can start with the ethical cleansing and being responsible towards its readers based on ethics. These guidelines of sensitivity have also been ignored in the spheres of covering topics like rape, drugs, violence, which have led to widespread unethical words used, as read and heard in the media.

Considering this damage by of journalism will persist, without a soul, so to speak. Considering the press is a body that points out short comings of others in society, now that the press sees its own short coming during the COVID-19 pandemic; beginning in February when the W.H.O. guidelines were updated tillJuly 30,2020 . As this study becomes known to the public, this the media cannot be measured, but will be effecting everyone's lives, given that the media points out short comings and often demands rectification of others in society for this be set right we should uphold the same strict measures as prescribed by the media themselves, a public apology, and possibly a media campaign to help reverse things sooner. The psychological phase we otherwise hang in the meanwhile will be stigma and fear!

\section{IMPORTANCE OF APOLOGY}

Without the apology, the ethic will be lost, only the structure is the time to come out and say SORRY, even if it can be seen as an innocent coincidence; for the benefit of mental health and reversing the effects of stigma created by unethical journalism an apology is obligatory, the media owes the world ethical reporting. The experiment was done and shown to journalistand editors in Goa, India with the intention of an apology; but as the study concluded the realization was made for the importance of an apology for all media houses. An apology along with implementing the compilation of sensitive verbiage detailed in FIGURE 1; directly by the reporter, sub editor, contributors and editors, who come together to run a media house, is what is necessary. Hence, while the solution also has been provided, the pointouts in this experiment have to be implemented to the ' $\mathrm{T}$ ' - as a journalist would say, 'to call it ethical journalism,' we must first come out, apologise, and thus make clear the faultyverbiage that has led to fear in the masses.

This is practise of ETHICAL JOURNALISM.

\section{REFERENCES}

[1] Ball-Rokeach, S. J., \& DeFleur, M. L. (1976). A dependency model of mass-media effects. Communication Research, 3, 3-21. http://dx.doi.org/10.1177/009365027600300101

[2] Frye, William B., "A qualitative analysis of sensationalism in media" (2005). Graduate Theses, Dissertations, and Problem Reports. 3218. https://researchrepository.wvu.edu/etd/3218

[3] Garfin, D. R., Holman, E. A., \& Silver, R. C. (2015). Cumulative exposure to prior collective trauma and acute stress responses to the Boston marathon bombings. Psychological Science, 26, 675683. http://dx.doi.org/10.1177/0956797614561043

[4] Garfin, D. R., Silver, R. C., \& Holman, E. A. (2020). The novel coronavirus (COVID-2019) outbreak: Amplification of public health consequences by media exposure. Health Psychology, 39(5), 355-357. https://doi.org/10.1037/hea0000875

[5] Holman, E. A., Garfin, D. R., \& Silver, R. C. (2014). Media's role in broadcasting acute stress following the Boston Marathon bombings. Proceedings of the National Academy of Sciences, 111, 93-98. http://dx.doi.org/10.1073/pnas.1316265110

[6] Jan Van den Bulck \& Kathleen Custers., Television exposure is related to fear of avian flu, anEcological Study across 23 member states of the European Union., European Journalof Public Health, Volume 19, Issue 4, August 2009, Pages 370-374, https://doi.org/10.1093/eurpub/ckp061

[7] Kasperson, R. E., Renn, O., Slovic, P., Brown, H. S., Emel, J., Goble, R., et al. (1988). The social amplification of risk: A conceptual framework. Risk Analysis, 8(2), 177-187. https://doi.org/10.1111/j.1539-6924.1988.tb01168.x

[8] Lachlan, K. A., Spence, P. R., Lin, X., Najarian, K., \& Del Greco, M. (2016). Social media and crisis management: CERC, search strategies, and Twitter content. Computers inHuman Behavior, 54, 647-652.http://dx.doi.org/10.1016/j.chb.2015.05.027

[9] Lee, S., Chan, L., Chau, A., Kwok, K., Kleinman, A., 2005. "The experience of SARS related stigma at Amoy Gardens," Social Science and Medicine, Vol.61, p.2038.

[10] Link, B., Phelan, J., 2001. "Conceptualizing stigma," Annual Review of Sociology, Vol.27,pp.363-8

[11] Pfefferbaum, B., Newman, E., Nelson, S. D., Nitiema, P., Pfefferbaum, R. L., \& Rahman, A. (2014). Disaster media coverage and psychological outcomes: Descriptive findings in the extant research. Current Psychiatry Reports, 16(9), 464.https://doi.org/10.1007/s11920-014-0464-x

[12] Rachel A. Smith, Xun Zhu,Edward L. Fink., Understanding the Effects of Stigma Messages: Danger Appraisal and Message Judgments., Health Commun. 2019 April; 34(4): 424- 436. http://doi:10.1080/10410236.2017.1405487 Smith RA (2007). Language of the lost: An explication of stigma communication. Communication Theory 17, 462-485. http://doi:10.1111/j.14682885.2007.00307.x Smith RA (2012). An experimental test of stigma communication content with a hypothetical infectious disease alert. Communication Monographs 79 522-538. http://doi:10.1080/03637751.2012.723811

[13] Smith RA (2014). Testing the model of stigma communication with a factorial experiment in an interpersonal context. Communication Studies, 65, 154-173. http://doi:10.1080/10510974.2013.851095 [PubMed: 25425853]

[14] Smith RA (2011). Stigma communication and health In Thompson TL, Parrott R, \& Nussbaum J (Eds.), Handbook of health communication (2nd ed., pp. 455-468). New York, NY: Taylor \& Francis.

[15] Thompson, R. R., Jones, N. M., Holman, E. A., \& Silver, R. C. (2019). Media exposure tomass violence events can fuel a cycle of distress. Science Advances, 5, eaav3502. http://dx.doi.org/10.1126/sciadv.aav3502

[16] Turan B, Hatcher AM, Weiser SD, Johnson M, Smith W, Turan JM. Framing mechanisms linking HIV-related stigma, adherence to treatment and health outcomes. Am J Public Health. 2017;107(6):863-9.

[17] Van Bortel, T., Basnayake, A., Wurie, F., Jambai, M., Koroma, A. S., Muana, A. T., et al. (2016). Psychosocial effects of an Ebola outbreak at individual, community and international levels. Bulletin of the World Health Organization, 94(3), 210-214. https://doi.org/10.2471/BLT.15.158543

[18] Williams SN, Armitage CJ, Tampe T, Dienes K., Public perceptions and experiences of social distancing and social isolation during the COVID-19 pandemic: a UK-based focus group study BMJ Open 2020; 10:e039334. doi: 10.1136/bmjopen2020-039334.

[19] World Health Organization, Advice on the use of masks in the 
context of COVID-19: Interimguidance, (5, June, 2020).

\section{SOURCES}

[20] Adnan Abid, Sunil Kataria, India Landfill site a COVID-19 risk for Scavengers, (2020, July 26). https://in.reuters.com/article/ushealth-coronavirus-india-medical- wast/scavengers-in-india-riskhealth-to-sift-coronavirus-debris-idINKCN24P0LA

[21] Archie Anant, MP HC upholds GOVT. Order for Non-Disclosure of COVID patients' Identity, (2020, May 30). https://lawsisto.com/legalnewsread/NTE2Mw==/MP-HCupholds-Govt-Order-for-Non-Disclosure-of-COVID-PatientsIdentity?

fbclid=IwAR3 odWfP2emiPUTeyLmEmcfzPdqsDTTH2fdCQeeF 0-pkHh7-5qsWAw4NYA

[22] Ayeshea Perera, Jeyaraj and Benicks: Outrage mounts over deaths in India police custody, (2020, June 27). https://www.bbc.com/news/world-asia-india-53202707

[23] Centers for Disease Control and Prevention (CDC), CERC: Psychology of a Crisis, (updated 2019) https://emergency.cdc.gov/cerc/ppt/CERC_Psychology_of_a_Crisi s.pdf

[24] CDC, Sources: National Center for Immunization and Respiratory Diseases (NCIRD), Division of Viral Diseases; Reducing Stigma, (2020, June 11). https://www.cdc.gov/coronavirus/2019ncov/daily-life-coping/reducing-stigma.html

[25] Claron Fidelis Mazarello, We \& Media Killed Our 14 yr. Old, (2020, July 30). archive.com/goanet@ lists.goanet.org/msg139586.html

[26] Debabrata Mohanty, Orissa High Court asks state to ensure Covid19 patients identities are protected, (2020, May 30). https://www.hindustantimes.com/india- news/orissa-high-courtasks-state-to-ensure-covid-19-patients-identities-areprotected/story-Z8Lu60JGwrYVJIwGhuRrvN.html? fbclid=IwAR1004w1zGUi_LyiQhSPqYvFAExEO8n07lIZJqppyx Mf9LOgp_effRiWge4

[27] Dhiraj Harmalkar, The social 'stigma' virus is affecting Vasco more than Coronavirus, (2020, June 22). https://www.heraldgoa.in/Goa/fighting-covid/The-social\%E2\%80\%98stigma\%E2\%80\%99-virus-is-affecting-Vasco-morethan-Coronavirus/162148

[28] Dr. N. Medappa, ICMR Bulletin Vol. 32, No. 11 \& 12., Live and Let Live: Acceptance of People Living with HIV/AIDS in an Era where Stigma and Discrimination Presist. (2002). https://main.icmr.nic.in/sites/default/files/icmr_bulletins/bunovdec $\underline{02 . p d f}$

[29] Goan Reporter News, (2020, July 29). Gabriel Couthino, Vasco gives His Covid-19 illness story in his own words. (Video) YouTube. https://www.youtube.com/watch?v=wPiweQrx-yU

[30] John Hopkins Medical, Stress Cardiomyopathy or "Broken Heart Syndrome"https://www.hopkinsmedicine.org/asc/faqs.html

[31] Kirk Seemple, 'Afraid to Be a Nurse': Health Workers Under Attack, (2020, April 27). https://www.nytimes.com/2020/04/27/world/americas/coronavirus -health- workers-attacked.html

[32] Pratik Parab, Fear Is The Key To Village Lockdowns, (2020, July 05). https://www.heraldgoa.in/Review/FEAR-IS-THE-KEY-TOVILLAGE-LOCKDOWNS/162647

[33] Press Trust of India, Indian-Origin Man Called "Chinese", Beaten up in Israel over Coronavirus, (2020, March 17). https://www.ndtv.com/indians-abroad/indian-origin- man-calledchinese-beaten-up-in-israel-over-coronavirus-2195857

[34] Press Trust of India, What purpose served by disclosing names of virus patients?: Bombay High Court, (2020, July 28). https://economictimes.indiatimes.com/news/politics-andnation/what-purpose-served- $\quad$ by-disclosing-names-of-viruspatients-bombay-high-court/articleshow/77215925.cms

[35] Press Trust of India, HC declines to pass order in PIL on Naming COVID-19 patients, (2020, Jully 31). https://www.outlookindia.com/newsscroll/hc-declines-to-passorder- on-pil-on-naming-covid19-patients/1906528? fbclid=IwAR1nVHUIOTPE5ojdMNkPNPNZrm63SrlihMU2PGvp
KcFmzKYK6Nf_I H4hZIQ

[36] Shari Harding, Five ways to Remove the Stigma Associated with Mental Health, (2017, July https://www.psychologytoday.com/us/blog/mentalstrength/201707/five-ways-remove-the-stigma-associated-mentalhealth

[37] TOI.in, Shocking! Cop brutally thrashes man for not wearing a mask in MP's Aliragpur; (Video), (2020, July 14). https://timesofindia.indiatimes.com/videos/news/shocking-copbrutally-thrashes-man- for-not-wearing-mask-in-mpsalirajpur/videoshow/76951948.cms

[38] UNAIDS., Terminology Guidelines, (2011). https://www.unaids.org/sites/default/files/media asset/JC2118 ter minology-guidelines en 1.pdf

[39] UNESCO, COVID-19-related discrimination and stigma: a global phenomenon? (25, May, 2020). https://en.unesco.org/news/covid19-related-discrimination-and-stigma-global-phenomenon

[40] World Health Organization. (2020). Advice on the use of masks in the context of COVID-19: interim guidance, 6 https://apps.who.int/iris/handle/10665/331693 April 2020. World Health Organization. . License: CC BY-NC-SA 3.0 IGO

[41] World Health Organization (W.H.O.), Constitution, (updated 2020).https://www.who.int/about/who-we-are/constitution

[42] World Health Organization, UNISEF, COVID-19 Stigma Guidelines, (2020, February24). https://www.who.int/docs/defaultsource/coronaviruse/covid19-stigma-guide.pdf 
TABLE 1

\begin{tabular}{|c|c|c|}
\hline $\begin{array}{l}\mathrm{Sr} \\
\mathrm{Nr}\end{array}$ & MEDIA SOURCE & $\begin{array}{l}\text { STIGMA FAIL -LINK- COVID-19 / CORONAVIRUS - Key-Word: } \\
\text { 'PATIENT' }\end{array}$ \\
\hline 1 & $\begin{array}{l}\text { THE HILL } \\
\text { USA - } 12 / 03 / 2020\end{array}$ & $\begin{array}{l}\text { https://thehill.com/changing-america/well-being/prevention-cures/487280- } \\
\text { nearly-70000-people-have-recovered-from }\end{array}$ \\
\hline 2 & $\begin{array}{l}\text { CHICAGO TRIBUNE } \\
\text { USA - 20/06/2020 }\end{array}$ & $\begin{array}{l}\text { https://www.chicagotribune.com/coronavirus/ct-covid-19-pandemic-chicago- } \\
\text { illinois-news-20200720-2bspyeyzqfe6nbvievfif7xxae-story.html }\end{array}$ \\
\hline 3 & $\begin{array}{l}\text { HURRIYET DAILY } \\
\text { NEWS } \\
\text { TURKEY - 16/04/2020 }\end{array}$ & $\begin{array}{l}\text { https://www.hurriyetdailynews.com/turkey-traces-contacts-to-find-cases-in- } \\
\text { fight-against-coronavirus-153924 }\end{array}$ \\
\hline 4 & $\begin{array}{l}\text { HOLLYWOOD } \\
\text { REPORTED } \\
\text { USA - 07/02/2020 }\end{array}$ & $\begin{array}{l}\text { https://www.hollywoodreporter.com/news/us-reports-new-record-coronavirus- } \\
\text { rise-1301537 }\end{array}$ \\
\hline 5 & $\begin{array}{l}\text { DAILY PROTHOM ALO } \\
\text { BANGLADESH - } \\
12 / 03 / 2020\end{array}$ & $\begin{array}{l}\text { https://en.prothomalo.com/bangladesh/second-coronavirus-patient-dies-4- } \\
\text { more-test-positive }\end{array}$ \\
\hline 6 & $\begin{array}{l}\text { INDIAN EXPRESS } \\
\text { INDIA - 22/07/2020 }\end{array}$ & $\begin{array}{l}\text { https://indianexpress.com/article/cities/mumbai/maharashtra-coronavirus-live- } \\
\text { updates-mumbai-pune-thane-palghar-coronavirus-latest-news-today-corona- } \\
\text { covid-19-cases-tracker-update-lockdown-6513961/ }\end{array}$ \\
\hline 7 & $\begin{array}{l}\text { THE GLOBE AND } \\
\text { MAIL } \\
\text { CANADA - 02/07/2020 }\end{array}$ & $\begin{array}{l}\text { https://www.theglobeandmail.com/canada/article-fewer-patients-hospitalized- } \\
\text { as-severity-of-coronavirus-cases-lessens/ }\end{array}$ \\
\hline 8 & $\begin{array}{l}\text { INQUIRER } \\
\text { PHILLIPEANS - } \\
\text { 04/07/2020 }\end{array}$ & $\begin{array}{l}\text { https://newsinfo.inquirer.net/1301832/philippines-logs-1494-new-covid-19- } \\
\text { patients-tally-now-at-41830 }\end{array}$ \\
\hline 9 & $\begin{array}{l}\text { REUTERS } \\
\text { NEWS MEDIA HOUSE } \\
-06 / 04 / 2020\end{array}$ & $\begin{array}{l}\text { https://in.reuters.com/article/czech-factors/czech-republic-factors-to-watch- } \\
\text { on-april-6-idINL8N2BU16D }\end{array}$ \\
\hline 10 & $\begin{array}{l}\text { THE SUN } \\
\text { UK - 13/06/2020 }\end{array}$ & $\begin{array}{l}\text { https://www.thesun.co.uk/news/12108611/half-coronavirus-patients-suffer- } \\
\text { heart-damage/ }\end{array}$ \\
\hline 11 & $\begin{array}{l}\text { AL JEZEERA } \\
\text { QATARI - 12/06/2020 }\end{array}$ & $\begin{array}{l}\text { https://www.aljazeera.com/news/2020/06/sees-summer-spike-coronavirus- } \\
\text { cases-states-reopen-200612142728196.html }\end{array}$ \\
\hline \multicolumn{3}{|c|}{ FOUND WHEN LOOKING FOR INFOBAE (ARGENTINA) } \\
\hline 12 & $\begin{array}{l}\text { WWW.LOC.GOV } \\
\text { USA - 07/05/2020 }\end{array}$ & $\begin{array}{l}\text { https://blogs.loc.gov/law/2020/05/israel-security-agency-surveillance-to-trace- } \\
\text { covid-19-patients-and-contacts-scrutinized/ }\end{array}$ \\
\hline \multicolumn{3}{|c|}{\begin{tabular}{|l} 
FOUND WHEN LOOKING FOR CORRIERE DELLA SERA (ITALY) \\
\end{tabular}} \\
\hline 13 & $\begin{array}{l}\text { VOICE OF AMERICA } \\
\text { USA - } 22 / 03 / 2020\end{array}$ & $\begin{array}{l}\text { https://www.voanews.com/science-health/coronavirus-outbreak/italy-reports- } \\
\text { hundreds-new-coronavirus-deaths }\end{array}$ \\
\hline
\end{tabular}


International Journal of Research and Innovation in Social Science (IJRISS) |Volume V, Issue X, October 2021|ISSN 2454-6186

\begin{tabular}{|c|c|c|}
\hline \multicolumn{3}{|c|}{ FOUND WHEN LOOKING FOR Mladá fronta Dnes (Czech) } \\
\hline 14 & $\begin{array}{l}\text { REMIX } \\
\text { CZECH - 05/06/2020 }\end{array}$ & $\begin{array}{l}\text { https://rmx.news/article/article/breakthrough-research-czech-scientist-can- } \\
\text { detect-the-coming-coronavirus-epidemic-before-it-spreads-among-people }\end{array}$ \\
\hline 15 & $\begin{array}{l}\text { THE INDEPENDENT } \\
\text { UK - 08/07/2020 }\end{array}$ & $\begin{array}{l}\text { https://www.independent.co.uk/news/health/coronavirus-uk-update-today- } \\
\text { covid-news-live-deaths-cases-lockdown-latest-a9607151.html }\end{array}$ \\
\hline 16 & $\begin{array}{l}\text { WALL STREET } \\
\text { JOURNAL } \\
\text { USA }-29 / 06 / 2020\end{array}$ & $\begin{array}{l}\text { https://www.wsj.com/articles/coronavirus-latest-news-06-29-2020- } \\
\underline{11593420521}\end{array}$ \\
\hline 17 & $\begin{array}{l}\text { THE DAILY MAIL } \\
\text { UK - 27/07/2020 }\end{array}$ & $\begin{array}{l}\text { https://www.dailymail.co.uk/wires/reuters/article-8563701/By-boat-foot- } \\
\text { Indian-state-hunts-plasma-COVID-patients.html }\end{array}$ \\
\hline 18 & $\begin{array}{l}\text { THE WASHINGTON } \\
\text { POST, USA - 01/07/2020 }\end{array}$ & $\begin{array}{l}\text { https://www.washingtonpost.com/health/2020/07/01/coronavirus-autopsies- } \\
\text { findings/ }\end{array}$ \\
\hline 19 & $\begin{array}{l}\text { CHINA DAILY } \\
\text { CHINA - 08/05/2020 }\end{array}$ & $\begin{array}{l}\text { https://covid- } \\
\text { 19.chinadaily.com.cn/a/202005/08/WS5eb4afd2a310a8b24115419a.html }\end{array}$ \\
\hline 20 & $\begin{array}{l}\text { SYDNEY MORNING } \\
\text { HERALD }\end{array}$ & $\begin{array}{l}\text { https://www.smh.com.au/national/coronavirus-australia-updates-live-masks- } \\
\text { to-be-compulsory-in-victoria-nsw-second-cluster-grows-death-toll-stands-at- }\end{array}$ \\
\hline & AUSTRALIA - 20/07/2020 & 122-20200720-p55diw.html \\
\hline $\begin{array}{l}\mathrm{Sr} \\
\mathrm{Nr}\end{array}$ & MEDIA SOURCE & $\begin{array}{l}\text { STIGMA FAIL -LINK- COVID-19 / CORONAVIRUS - Key-Word: } \\
\text { 'PATIENT' }\end{array}$ \\
\hline 21 & $\begin{array}{l}\text { THE ASAHI SHIMBUN } \\
\text { JAPAN - } 15 / 06 / 2020\end{array}$ & http://www.asahi.com/ajw/articles/13459807 \\
\hline 22 & $\begin{array}{l}\text { EXPRESS } \\
\text { UK - 03/03/2020 }\end{array}$ & $\begin{array}{l}\text { https://www.express.co.uk/news/world/1250084/Coronavirus-latest-news- } \\
\text { patient-symptoms-COVID-19-Singapore-China-Wuhan }\end{array}$ \\
\hline 23 & $\begin{array}{l}\text { THE GUARDIAN } \\
\text { USA - 20/07/2020 }\end{array}$ & $\begin{array}{l}\text { https://www.theguardian.com/commentisfree/2020/jul/20/some-covid-19- } \\
\text { patients-are-struggling-to-get-doctors-to-listen-heres-why }\end{array}$ \\
\hline 24 & $\begin{array}{l}\text { USA TODAY } \\
\text { USA - 20/06/2020 }\end{array}$ & $\begin{array}{l}\text { https://www.usatoday.com/story/news/health/2020/06/20/coronavirus-covid- } \\
\text { 19-symptoms-can-last-months-some-patients/3207573001/ }\end{array}$ \\
\hline 25 & $\begin{array}{l}\text { EL PAIS } \\
\text { SPAIN - 16/07/2020 }\end{array}$ & $\begin{array}{l}\text { https://english.elpais.com/society/2020-07-16/the-mystery-of-madrids-lack-of- } \\
\text { coronavirus-outbreaks.html }\end{array}$ \\
\hline 26 & $\begin{array}{l}\text { MARCA } \\
\text { SPAIN - 09/05/2020 }\end{array}$ & $\begin{array}{l}\text { https://www.marca.com/en/lifestyle/2020/05/09/5eb67d7c268e3ede798b456b. } \\
\text { html }\end{array}$ \\
\hline 27 & $\begin{array}{l}\text { NEW YORK TIMES } \\
\text { USA - 29/06/2020 }\end{array}$ & https://www.nytimes.com/2020/06/29/us/coronavirus-today.html \\
\hline 28 & $\begin{array}{l}\text { MANORAMA ONLINE } \\
\text { INDIA - 26/06/2020 }\end{array}$ & $\begin{array}{l}\text { https://www.manoramaonline.com/news/latest-news/2020/06/26/nurse-and- } \\
\text { husband-about-covid-treatment-experience.html }\end{array}$ \\
\hline 29 & $\begin{array}{l}\text { HOUSTON } \\
\text { CHRONICLE } \\
\text { USA - } 18 / 07 / 2020\end{array}$ & $\begin{array}{l}\text { https://www.houstonchronicle.com/news/houston- } \\
\text { texas/houston/article/Saturday-coronavirus-updates-Record-number-of- } \\
\text { 15418198.php }\end{array}$ \\
\hline
\end{tabular}


International Journal of Research and Innovation in Social Science (IJRISS) |Volume V, Issue X, October 2021|ISSN 2454-6186

\begin{tabular}{|c|c|c|}
\hline 30 & $\begin{array}{l}\text { TIMES OF INDIA } \\
\text { INDIA - 17/07/2020 }\end{array}$ & $\begin{array}{l}\text { https://timesofindia.indiatimes.com/city/pune/less-than-half-of-punes-868-icu- } \\
\text { beds-for-covid-care/articleshow/77010047.cms }\end{array}$ \\
\hline 31 & $\begin{array}{l}\text { THE WIRE } \\
\text { USA - } 28 / 06 / 2020\end{array}$ & https://thewire.in/world/coronavirus-how-spain-left-its-elderly-to-die \\
\hline \multicolumn{3}{|c|}{ FOUND WHEN LOOKING FOR DIE WELT (GERMANY) } \\
\hline 32 & $\begin{array}{l}\text { DEUTSCHE WELLE } \\
\text { GERMANY - 09/05/2020 }\end{array}$ & $\begin{array}{l}\text { https://www.dw.com/en/coronavirus-latest-germanys-infection-rate-rises- } \\
\text { again/a-53376414 }\end{array}$ \\
\hline \multicolumn{3}{|c|}{ FOUND WHEN LOOKING FOR KOMSOMOLSKALY PRAVDA (RUSSIA) } \\
\hline 33 & $\begin{array}{l}\text { MEDUZA } \\
\text { RUSSIA - 23/04/2020 }\end{array}$ & https://meduza.io/en/feature/2020/04/23/we-should-know-them-by-name \\
\hline 34 & $\begin{array}{l}\text { TASS } \\
\text { RUSSIA - 20/03/2020 }\end{array}$ & https://tass.com/russia/1133403 \\
\hline \multicolumn{3}{|c|}{ FOUND THESE WHEN LOOKING FOR LE MONDE (FRANCE) } \\
\hline 35 & $\begin{array}{l}\text { SORTIR A PARIS } \\
\text { FRANCE - 08/04/2020 }\end{array}$ & $\begin{array}{l}\text { https://www.sortiraparis.com/news/coronavirus/articles/214294-coronavirus- } \\
\text { plasma-transfusions-effective-against-the-disease/lang/en }\end{array}$ \\
\hline \multicolumn{3}{|c|}{ FOUND THIS WHEN LOOKING FOR NOHON KEIZAI SHIMBUN (JAPAN) } \\
\hline 36 & $\begin{array}{l}\text { NIPPON } \\
\text { JAPAN - 15/04/2020 }\end{array}$ & https://www.nippon.com/en/news/ntv20200415001/ \\
\hline \multicolumn{3}{|c|}{ FOUND WHEN LOOKING FOR EL MUNDO (SPAIN) } \\
\hline 37 & $\begin{array}{l}\text { WORLDOMETERS } \\
\text { UN - 28/07/2020 }\end{array}$ & https://www.worldometers.info/coronavirus/?utm_campaign=homeAdvegas1 \\
\hline \multicolumn{3}{|c|}{ FOUND WHEN LOOKING FOR LE FIGARO (FRANC) } \\
\hline 38 & $\begin{array}{l}\text { INDIA TIMES } \\
\text { INDIA - 06/04/2020 }\end{array}$ & $\begin{array}{l}\text { https://economictimes.indiatimes.com/news/international/world-/thousands- } \\
\underline{\text { sign-french-call-for-chloroquine-in-virus-fight/articleshow/75008701.cms? }} \\
\underline{\text { from=mdr }}\end{array}$ \\
\hline \multicolumn{3}{|c|}{ FOUND ON GOOGLE SEARCH WHEN LOOKING FOR BILD (CHINA) } \\
\hline 39 & $\begin{array}{l}\text { GLOBAL TIMES } \\
\text { CHINA - 20/04/2020 }\end{array}$ & https://www.globaltimes.cn/content/1186214.shtml \\
\hline \multicolumn{3}{|c|}{ FINAL 10 CHOSEN TO COVER THE WORLD REGIONS AS BEST AS POSSIBLE } \\
\hline 40 & $\begin{array}{l}\text { NEW DELHI TV } \\
\text { INDIA - 28/07/2020 }\end{array}$ & $\begin{array}{l}\text { https://www.ndtv.com/india-news/coronavirus-jhansi-covid-patient-records- } \\
\text { message-at-hospital-hours-before-death-total-negligence-2270042 }\end{array}$ \\
\hline 41 & $\begin{array}{l}\text { SADA AL-BALAD } \\
\text { LEBANON - 03/05/2020 }\end{array}$ & https://see.news/coronavirus-update-egypt-to-establish-plasma-factory/ \\
\hline 42 & $\begin{array}{l}\text { PHARMACEUTICAL } \\
\text { MAGAZINE }\end{array}$ & $\begin{array}{l}\text { https://www.pharmaceutical-technology.com/news/coronavirus-a-timeline-of- } \\
\text { how-the-deadly-outbreak-evolved/ }\end{array}$ \\
\hline & RUSSIA - 28/04/2020 & \\
\hline $\mathbf{S r}$ & MEDIA SOURCE & STIGMA FAIL -LINK- COVID-19 / CORONAVIRUS - Key-Word: \\
\hline
\end{tabular}


International Journal of Research and Innovation in Social Science (IJRISS) |Volume V, Issue X, October 2021|ISSN 2454-6186

\begin{tabular}{|c|c|c|}
\hline $\mathbf{N r}$ & & 'PATIENT' \\
\hline 43 & $\begin{array}{l}\text { YAHOO NEWS } \\
\text { USA - 22/07/2020 }\end{array}$ & $\begin{array}{l}\text { https://news.yahoo.com/coronavirus-updates-connecticut-finds-90- } \\
\text { 104526396.html }\end{array}$ \\
\hline 44 & $\begin{array}{l}\text { Sada Al-Balad } \\
\text { LEBANON - 03/05/2020 }\end{array}$ & https://see.news/coronavirus-update-egypt-to-establish-plasma-factory/ \\
\hline 45 & $\begin{array}{l}\text { DIARIO AS } \\
\text { SPAIN - 23/07/2020 }\end{array}$ & https://en.as.com/en/2020/07/22/latest_news/1595399541_375105.html \\
\hline 46 & $\begin{array}{l}\text { FOLHA } \\
\text { BRAZIL - 24/06/2020 }\end{array}$ & $\begin{array}{l}\text { https://www1.folha.uol.com.br/internacional/en/scienceandhealth/2020/06/bra } \\
\text { zil-records-1364-deaths-by-covid-19-in-24-hours-second-highest-daily-value- } \\
\text { ever-recorded.shtml }\end{array}$ \\
\hline 47 & $\begin{array}{l}\text { MEED } \\
\text { SAUDI ARABIA - } \\
28 / 07 / 2020\end{array}$ & https://www.meed.com/latest-news-on-the-pandemics-economic-impact \\
\hline 48 & $\begin{array}{l}\text { NORDSTJERNAN } \\
\text { SWEEDEN - 30/03/2020 }\end{array}$ & http://www.nordstjernan.com/news/briefs/8969/ \\
\hline 49 & $\begin{array}{l}\text { TIMES LIVE } \\
\text { SOUTH AFRICA - } \\
13 / 07 / 2020\end{array}$ & $\begin{array}{l}\text { https://www.timeslive.co.za/sunday-times/business/2020-07-13-union-numsa- } \\
\text { brings-drug-remdesivir-to-sa-to-treat-covid-19-patients/ }\end{array}$ \\
\hline 50 & $\begin{array}{l}\text { PRESS TRUST OF } \\
\text { INDIA } \\
\text { INDIA - 28/04/2027 }\end{array}$ & $\begin{array}{l}\text { http://www.ptinews.com/news/11677746_What-purpose-served-by-disclosing- } \\
\text { names-of-virus-patients--HC.html }\end{array}$ \\
\hline
\end{tabular}




\section{FIGURE 1}

\section{TOWARDS A 'PEOPLES FIRST' LANGUAGE - PRESS SENSITIZATION FOR PRINT MEDIA - FOR COVID-19: (ENGLISH)}

\begin{tabular}{|c|c|}
\hline $\begin{array}{l}\text { Stigmatizing Language } \\
\text { ("Try not to use") }\end{array}$ & $\begin{array}{l}\text { Preferred Language } \\
\text { ("Use this instead") }\end{array}$ \\
\hline COVID - positive & People who have / treated for / recovering from COVID-19 \\
\hline COVID-19 suspects & People with / treated for / recovering from COVID-19 symptoms \\
\hline COVID-19 / Coronavirus cases & People who have / treated for / recovering from COVID-19 \\
\hline Suspected Cases | COVID-19 suspects & People who are presumptive for / may have COVID-19 \\
\hline CORONA or COVID-19 patient & People with / treated for / recovering from COVID-19 symptoms \\
\hline Positives or COVIDers & People with / treated for / recovering from COVID-19 \\
\hline $\begin{array}{l}\text { Died of CORONA/COVID-19 } \\
\text { To die of CORONA/COVID }\end{array}$ & $\begin{array}{l}\text { Died of COVID-19 related illness } \\
\text { To die from COVID-19 related complications }\end{array}$ \\
\hline \multicolumn{2}{|c|}{ The word INFECTION \& TRANSMISSION needs to change to ACQUIRING OR CONTRACTING } \\
\hline \multicolumn{2}{|c|}{ Never use "infected" when referring to a person or persons } \\
\hline COVID - infected & $\begin{array}{l}\text { People treated for / recovering from COVID-19 } \\
\text { Diagnosed with COVID-19 }\end{array}$ \\
\hline New infections & New COVID-19 acquisitions \\
\hline CORONA/COVID infections & COVID-19 contractions or acquisitions \\
\hline Number of infections & $\begin{array}{l}\text { Numbers diagnosed with COVID-19 } \\
\text { Number of COVID-19 acquisitions }\end{array}$ \\
\hline Became infected & Contracted or acquired \\
\hline CORONA/COVID-exposed infant & Infant exposed to COVID-19 \\
\hline $\begin{array}{l}\text { A drug that prevents } \\
\text { CONRONA / COVID-19 infection } \\
\text { Infection }\end{array}$ & $\begin{array}{c}\text { A drug that prevents the acquisition of COVID-19 } \\
\text { People with / treated for / recovering from COVID-19 symptoms / } \\
\text { Survivor(s), } \\
\text { Person who died after contracting COVID-19 }\end{array}$ \\
\hline CORONA/COVID orphans & $\begin{array}{l}\text { Children orphaned by loss of parents/guardians who died of } \\
\text { COVID-19 related complications }\end{array}$ \\
\hline $\begin{array}{l}\text { To Catch / To Contract / To Transmit - } \\
\text { CORONA/COVID-19 }\end{array}$ & $\begin{array}{l}\text { To be diagnosed for having ... - or - a COVID-19 diagnosis, to } \\
\text { develop - or - Developed SYMPTOMS OF COVID-19 }\end{array}$ \\
\hline $\begin{array}{l}\text { Deadly, Death sentence, } \\
\text { Fatal condition, or } \\
\text { Life-threatening condition }\end{array}$ & $\begin{array}{l}\text { COVID-19 is not fatal, except with already existing high-risk co- } \\
\text { morbidities. Hence, THESE WORDS ONLY ADD FEAR. }\end{array}$ \\
\hline Clean, as in "I am clean, are you" & $\begin{array}{l}\text { Avoid this term. } \\
\text { Referring to yourself or others as being "clean" suggests that } \\
\text { those living with COVID-19 are dirty. }\end{array}$ \\
\hline Quarantine person & Person recovering under quarantine health facilities. \\
\hline Isolated person & Person recovering in private, with social distancing / self isolation \\
\hline \multicolumn{2}{|c|}{$\begin{array}{l}\text { SARS-CoV-2 may also be interchangeable with COVID-19 depending on better understanding of the context where use of CORONA and COVID -19 } \\
\text { or SARS-COV-2 can accordingly be applied. } \\
\text { This compilation has been based on W.H.O., UNESCO and HIV sensitization guidelines and edited to directly help news output for media houses } \\
\text { exposing words adding to stigma, fear and confusion among readers. }\end{array}$} \\
\hline \multicolumn{2}{|l|}{$\begin{array}{l}\text { Compiled by: Claron Fidelis Mazarello } \\
\text { technical inputs by: Tori Connor }\end{array}$} \\
\hline with inputs by: Peter $F$. Borges & July 21,2020 \\
\hline
\end{tabular}

